\title{
THE SCOPE OF SUPREME COURT REVIEW IN OBSCENITY CASES
}

$\mathrm{I}_{\mathrm{N}}$ Roth v. United States, the United States Supreme Court held that the test for obscenity is "whether to the average person, applying contemporary community standards, the dominant theme of the material taken as a whole appeals to prurient interest."1 Material that met this test was excluded from the realm of constitutionally protected expression, since it was "utterly without redeeming social importance" and, therefore, could contribute nothing to the free exchange of ideas. ${ }^{2}$ Nevertheless, the Roth case has left unresolved the meaning of "community"3 and the scope of judicial review accorded by the Supreme Court to convictions under state and local obscenity statutes. In Jacobellis $v$. Ohio, ${ }^{4}$ where the manager of a movie theater was convicted ${ }^{5}$ under an Ohio statute ${ }^{6}$ for showing Les Amants, these issues were considered when the Court was unable to muster a majority to join in an opinion.

Justices Brennan and Goldberg asserted that it was the mandatory duty of the Court in each case to review de novo the evidentiary basis for the finding of obscenity, ${ }^{7}$ and then to apply the Roth test,

1354 U.S. 476,489 (1957).

2Id. at 484. For discussions of the Roth test, see Henkin, Morals and the Constitution: the Sin of Obscenity, 63 CoLum. L. REv. 391 (1963); Kalven, The Metaphysics of the Law of Obscenity, 1960 Sup. Cr. REv. 1; Lockhart \& McClure, Censorship of Obscenity: The Developing Constitutional Standards, 45 MINN. L. REv. 5 (1960).

"There is no explicit discussion in Roth of the significance of "community." However, in Jacobellis $\%$. Ohio, Mr. Justice Brennan, the author of the opinion of the court in Roth, stated that he and Justice Goldberg "reaffirm the position taken in Roth to the effect that the constitutional status of an allegedly obscene work must be determined on the basis of a national standard." 378 U.S. 184, 195 (1964). (Emphasis added.)

' 378 U.S. 184 (1964). Jacobellis is the first case involving the application of a state obscenity statute in which the Supreme Court has rendered a judgment accompanied by opinions. In Albert v. California, 354 U.S. 476 (1957), the companion case decided with Roth, the issue was the constitutionality of the statute in light of the admitted obscenity of the material. Although Smith v. California, 361 U.S. 147 (1959) involved the application of a statute, this issue was never reached; the case turned upon the unconstitutionality of the statute for lack of any requirement of scienter. Another case involving the application of a state statute to the challenged material, Times Film Corp. v. City of Chicago, 355 U.S. 371 (1957), was simply reversed per curiam.

173 Ohio St. 22, 179 N.E.2d 777 (1962), affirming 115 Ohio App. 226, 175 N.E.2d 123 (1961).

OHIO Rev. Code ANN. \$2905.34 (Supp. 1964).

7378 U.S. at $187-90$. Although there was no opinion of the court, the Brennan- 
construing "community" as the nation at large..$^{8}$ Justices Black and Douglas concurred in the judgment on the broader ground that any obscenity law abridges the freedom of expression guaranteed by the first and fourteenth amendments. ${ }^{9}$ Mr. Justice Stewart's concurrence was predicated on his belief that Les Amants did not represent the "hard-core poronography" which alone can be constitutionally banned. ${ }^{10}$ Mr. Justice White concurred without opinion.

The Chief Justice, joined by Mr. Justice Clark, dissented, arguing in favor of a "sufficient evidence" review.11 Feeling that Jacobellis' conviction was supported by the requisite evidence, they would have affirmed. Mr. Justice Harlan dissented on the ground that the Court should reverse state obscenity convictions only when such convictions are "irrational"; having viewed Les Amants, he felt that Jacobellis' conviction could not be so characterized. ${ }^{12}$

\section{The Brennan-Goldberg View: De Novo REview AND A National "Community"}

According to Justices Brennan and Goldberg, the duty to undertake a de novo review arises from the Court's decision in Roth, under which any finding of obscenity necessarily entails a judgment that the challenged material is not constitutionally protected..$^{13}$

Goldberg language has been referred to as the "holding" in Jacobellis. See People v. Bruce, 202 N.E.2d 497, 498 (Ill. 1964).

8378 U.S. at 192.95.

'Id. at 196. Justices Black and Douglas have frequently stated that freedom of expression cannot be abridged merely by reference to the thoughts to which a particular material might give rise. In their view, dissemination and "consumption" of obscene material can be regulated only if it can be proven to have resulted in antisocial conduct which is a proper subject of governmental control. See Roth v. United States, 354 U.S. at 509 (dissenting opinion).

${ }^{10} \mathrm{Mr}$. Justice Stewart admitted that he would not attempt, and perhaps could not define hard-core pornography. He merely stated: "I know it when I see it, and the motion picture involved in this case is not that." 378 U.S. at 197.

11 Id. at 202-03.

${ }^{12} I d$. at 203-04. Mr. Justice Harlan is quicker to reverse a conviction under a federal obscenity statute since he feels that obscenity is primarily an issue reserved to the states and, therefore, an area of merely attenuated federal interest. Thus he dissented in Roth, 354 U.S. at 503, while he concurred in the companion case. Id. at 500. This dual standard is reflective of a danger envisioned by Justice Harlan in federal censorship. Federal prohibition of the use of the facilities of interstate commerce for the dissemination of material can effectively deprive the whole country of access to the material. If merely one state bans certain material it may still be available in other states. See Manuel Enterprises, Inc. v. Day, 370 U.S. 478,488 (1962) (Harlan, J.). Moreover, this dualism is a projection of Harlan's theory that the strength of our federal system lies in the diversity and incongruity between the states comprising the system, each state being one of "forty-eight experimental social laboratories." 354 U.S. at 505.

18378 U.S. at 188 . 
Under Roth, a determination of obscenity is no mere finding of fact, but a "constitutional judgment" which cannot be left exclu. sively to the trier-of-fact or a state's appellate courts. ${ }^{14}$ The Court's responsibility in obscenity cases is the same as in other cases involving state court "constitutional judgments" under the due process clause. ${ }^{15}$ This is especially true in first amendment cases, ${ }^{10}$ as evidenced by the Court's willingness to review a record de novo for purposes of determining whether conduct has in fact constituted: a breach of the peace or unlawful assembly; 17 a clear and present danger to the impartial administration of justice; ${ }^{18}$ incitement to insurrection; ${ }^{19}$ or publication with actual malice. ${ }^{20}$

Arguing that the application of rights guaranteed by the federal constitution should not vary from state to state, much less from community to community, ${ }^{21}$ Justices Brennan and Goldberg construed the term "community" in the Roth test in a national sense, as signifying "society at large; . . . the public, or people in general."22 They supported their construction by recalling that Judge Learned Hand, who coined the phrase "contemporary community standards" in obscenity litigation, used it in a temporal and not a geographic

1'See Zeitlin v. Amebergh, 59 Cal. 2d 901, 909-10, 383 P.2d 152, 157-58, 31 Cal. Rptr. 800, 805-06 (1963); Attorney General v. Book Named "Tropic of Cancer," 945 Mass. 11, 13, 184 N.E.2d 328, 329-30 (1962); People v. Richmond County News, Inc. 9 N.Y.2d 578, 580-81, 175 N.E.2d 681, 682, 216 N.Y.S.2d 369, 370 (1961).

${ }^{15}$.E.g., Watts v. Indiana, 398 U.S. 49, 51 (1949); Norris v. Alabama, 294 U.S. 587, 590 (1935).

10 "[W]e reject, in this case, the argument that there is greater latitude for state action under the word 'liberty' under the Fourteenth Amendment than is allowed to Congress by the language of the First Amendment." Roth v. United States, 954 U.S. at 492 n.31.

${ }^{12}$ Edwards v. South Carolina, 372 U.S. 229, 235 (1963); Feiner v. New York, 940 U.S. 315, 316 (1951); Niemotko v. Maryland, 340 U.S. 268, 271 (1951).

${ }^{20}$ Craig v. Harney, 331 U.S. 367, 373 (1947); Pennekamp v. Florida, 328 U.S. 391, 335 (1946); Bridges v. California, 314 U.S. 252, 271 (1941).

${ }^{20}$ Herndon v. Lowry, 301 U.S. 242, 247 (1947).

${ }^{20} \mathrm{New}$ York Times Co. v. Sullivan, 376 U.S. 254, 285 (1964).

21378 U.S. at 194-95.

22378 U.S. at 193 (quoting Webster, New International Dictionary 542 (2d ed. 1949)); see note 3 supra. Justices Brennan and Goldberg also alluded to a factor which Justice Harlan in Manual Enterprises, lnc. v. Day, 370 U.S. 478, 482 (1962) considered to be a condition precedent to any consideration of the issue of obscenity -that is, whether the challenged material exceeds the limits of candor of the com. munity. They construed the Roth standard to include this factor since it was included in the definition of obscenity in the Model Penal Code of the American Law Institute, which was favorably mentioned in Roth v. United States, 354 U.S. at 487 n.20. 378 U.S. at 191-92. Furthermore, Brennan and Goldberg emphasized that the social importance of the challenged material is not to be weighed against its "offensiveness." To be obscene the material must be utterly without redecming social importance. Id. at 191. 
sense.23 Variant local standards of obscenity would, in their view, entail the intolerable consequence of depriving some segments of the nation of access to material there deemed acceptable. ${ }^{24}$ For example, a residential suburban community might depend entirely upon the motion-picture theater and library "in town" for access to such forms of expression. Were the "town" considered the relevant community by whose standards an obscenity prosecution would be tried, the suburban community, if broader in outlook, might be deprived of ready access to forms of expression which by its own standards would be constitutionally permissible. ${ }^{25}$ Moreover, the restrictive standards of a single community might induce national disseminators to by-pass an entire state rather than risk costly involvement in obscenity litigation. ${ }^{26}$ Should national disseminators feel compelled to distribute within a particular state only material conforming to the standards of its most conventional communities, the result would be an indirect system of distributor censorship.27

\section{The Warren-Clark View: Sufficient \\ EVIDENCE AND A LOCAL "CoMmunity"}

While failing to challenge directly the view that a finding of obscenity under Roth necessarily entails a "constitutional judgment," the Chief Justice and Justice Clark take issue with the Brennan-Goldberg concept of the Court's proper role in obscenity litigation. ${ }^{28}$ The crux of their dissent is a feeling of disappointment and frustration at the inability of the Court to provide workable guide-

${ }^{23}$ See United States v. Kennerley, 209 Fed. 119, 121 (S.D.N.Y. 1913) (cited in 378 U.S. at 192-93).

26 Manual Enterprises, Inc. v. Day, 370 U.S. 478, 488 (Harlan, J.).

${ }^{25}$ The textual example also illustrates the problem of drawing community lines. The term "community" need not signify a geo-political subdivision. Whereas in Jacobellis, the defendant is prosecuted under a state obscenity statute, the "community" might reasonably be held to be the entire state of Ohio. However, if the jury sitting in Cuyahoga County was applying the "contemporary community standards" of the state of Ohio, it seems anomalous that the film was shown without incident in other cities of the state. See 378 U.S. at 196.

${ }^{20}$ In Jacobellis, for example, an Ohio statute, and not a Cleveland Heights ordinance, was involved. The statute was construed and applied by the Supreme Court of Ohio. Prior to this litigation the film had been shown in other major Ohio. cities without incident. It is questionable whether following Jacobellis' conviction a dissiminator would chance a showing of Les Amants or a comparable film within the state.

${ }^{27}$ Cf. Butler v. Michigan, 352 U.S. 380 (1957).

${ }^{28}$ Warren and Clark neither challenge nor attempt to distinguish the analogous cases cited by Justices Brennan and Goldberg as indicating a duty of de novo review. See notes $14-20$ supra. 
lines in obscenity cases which, they note with consternation, have proliferated since Roth. ${ }^{29}$ By granting de novo review in each case, the Court establishes itself as an "ultimate censor," at once depriving local communities of the right to protect their "moral fiber" according to their own standards and impeding effective administration of justice by unproductive consumption of the Court's limited time. ${ }^{30}$

Warren and Clark purport to find the solution to these problems in limiting the Surpreme Court to a "sufficient evidence" review. However, they fail to indicate what type and quantum of evidence would meet such a standard. The "sufficient evidence" requirement is described as "something more than merely any evidence," but something less than the "substantial evidence" requirement of Universal Camera Corp. v. $N L R B, 31$ under which the lower courts were admonished to balance both sides of the record in deciding whether the evidence supported the decision. Whether the "sufficient evidence" standard entails perusal of only one side of the record does not appear in the Chief Justice's opinion. ${ }^{32}$

The Warren-Clark advocacy of a "sufficient evidence" review is apparently premised on a feeling that the local community can

80378 U.S. at $199-200$.

${ }^{20}$ Id. at 202.

21340 U.S. 474 (1951) (cited in 378 U.S. at 203).

22 The Chief Justice's definition of sufficient evidence was "something less than substantial evidence on the record (including the allegedly obscene material) as a whole." 378 U.S. at 203. The parenthetical does nothing to indicate whether the Warren-Clark view contemplates reading or viewing the material, merely glancing at it, or completely disregarding it. Looking at only one side of the record would seem the most obvious difference between "sufficient evidence" and the "substantial evidence" requirement of Universal Camera. Nevertheless, the definition leaves room for at least three other standards of judicial review. (1) Look to both sides of the record, including the challenged material, and affirm if the conviction is at least arguably correct. One problem inherent in this interpretation is that it requires reading or viewing the challenged material and hence consumes as much time as de novo review. Moreover, it is diffcult to see any real difference between this and the scope of review required in Universal Camera; both would require affirming a judgment which, after considering the record as a whole, is supported by the evidence. (2) Look to both sides of the record, merely glancing at the objectionable material, and affirm if the conviction is at least arguably correct. A superficial perusal of the material, however, would seem to accentuate the more objectionable aspects while obscuring the "dominant theme." Compare note 51 infra. (3) Look to both sides of the record, disregarding the challenged material, and affirm if the conviction is at least arguably correct. If this is the test, disregarding the material may leave no record to review in those states which apply the ultimate facts rule of evidence. See text accompanying notes 33-40 infra. Furthermore, the constitutional claim on which review is sought in obscenity cases is that a statute or ordinance has been unconstitutionally applied, and it is difficuit to see how the Court could review a determination that material is in fact obscene without looking at the material. 
properly judge the challenged material by its own standards. They believe "that there is no provable national standard and perhaps there should be none." 33 Indeed, if "community" be given a local significance, the local trier-of-fact is best qualified to determine how the average person would apply community standards in judging the appeal of the dominant theme of the challenged material taken as a whole. Compared to a local jury, the Supreme Court is manifestly incompetent to ascertain and apply local community standards.

\section{The Record in Obscentty Gases}

The record presented to a reviewing court in most obscenity cases consists primarily of undisputed primary facts. ${ }^{34}$ Furthermore, it has been held that the state satisfies its burden of going forward merely by offering evidence that the defendant knowingly ${ }^{35}$ disseminated the challenged material and by placing the material in evidence as an exhibit. ${ }^{36}$ The state need proffer no evidence as to the dominant theme of the material, ${ }^{37}$ nor of contemporary community standards; both have been considered legal conclusions or "ultimate

3s 378 U.S. at $200-01$.

"The "speech" in question and the fact of its dissemination is generally admitted. See Lockhart \& McClure, supra note 2, at 116.

${ }^{28}$ The Supreme Court in Smith v. California, 361 U.S. 147 (1959), held that a statute making the dissemination of obscenity a crime is unconstitutional unless the element of scienter is included. It left undetermined the kind of mens rea that is constitutionally necessary since the statute in question was completely devoid of scienter and imposed an absolute criminal liability.

A related danger, peculiar to the area of first amendment freedoms, arises where, due to a lack of definitive legal standards, the subsequent punishment meted out takes the form of a "prior restraint." If the definition of constitutionally protected material is vague, the individual may be induced to temper his speech to a greater degree than is constitutionally necessary. This is both a tacit form of inhibition of individual freedoms and a deprivation of public access to constitutionally protected expression. The range of permissible subsequent punishment in the first amendment field should be so circumscribed as to provide adequate latitude for the exercise of guaranteed expression, and this cannot be accomplished by merely requiring that the range of subsequent punishment be explicit enough to satisfy the notice requirements of due process. Although this may be adequate protection of individual freedoms, it dilutes public access to constitutionally protected speech by imposing self-censorship on those prospective speakers who fear the danger of subsequent punishment.

${ }^{80}$ See City of Chicago v. Kimmel, 201 N.E.2d 386, 388 (IIl. 1964); City of Chicago v. Doe, 47 Ill. App. 2d 460, 466-67, 197 N.E.2d 711, 714 (IIl. 1964); Yudkin v. State, $229 \mathrm{Md}$. 223, 227, $182 \mathrm{~A} .2 \mathrm{~d} 799,800-01$ (1962). A similar case arising under a federal statute is Kahm v. United States, 300 F.2d 78, 84 (5th Cir. 1962). 1964).

${ }^{37}$ Cf. United States v. West Coast News Co., 228 F. Supp. 171, 182-83 (W.D. Mich. 
facts" within the exclusive province of the jury. ${ }^{38}$ State evidence on the appeal of the material to prurient interests is unnecessary since this issue is autoptically handled by the jury, ${ }^{30}$ as well as being a legal conclusion. ${ }^{40}$

Courts seem especially reluctant to admit purportedly expert testimony on the above matters, since these issues are so peculiarly within the competence of the local jury. ${ }^{41}$ Even assuming such testimony is admissible, the expert must first establish his qualifications, and it is difficult to qualify as an expert on "contemporary community standards." 42 Some courts will permit the defendant to establish by expert testimony that the challenged material did not exceed the community limits of candor by showing that similar material was prevalent and tolerated in the community. ${ }^{43}$ If testimony as to the similarity of the challenged material to that alleged to be tolerated by the community were not admitted, under the Roth "material-as-a-whole" requirement, the jury would have to spend valuable court time considering as a whole each exhibit claimed to be comparable. ${ }^{44}$ Moreover, defendants are universally permitted

${ }^{88}$ See cases cited note 36 supra. See generally 7 Wigmore, Evidence $\$ 1920$ (8d ed. 1940) (critical of ultimate fact rule).

The Roth requirement of judging the material as a whole gives rise to the evidentiary problem of presenting the material to the jury. It has been unsuccessfully argued that the book as a whole must be read aloud to the jury. See Alexander v. United States, 271 F.2d 140, 144-45 (8th Cir. 1959); United States v. West Coast News Co., supra note 37, at 178-79. Two alternatives are presented: the exhibits can he taken into the juryroom to be perused by the jury during their deliberation, Alexander v. United States, supra, or they can be given to the jury for perusal in open court at the close of the state's case, United States v. West Coast News Co., supra; sec Yudkin v. State, 229 Md. 223, 225, 182 A.2d 798, 800 (1962). Although more time consuming for the court, the latter alternative is the preferred view since it is more certain that the jury will in fact peruse the material and it renders the defendant's cace more comprehensible. See United States v. West Coast News Co., supra at 179.

${ }^{30}$ City of Chicago v. Doe, 197 N.E.2d 711, 714 (Ill. 1964). Professor Wigmore classifies all evidential sources as testimonial, circumstantial, and autoptical. The latter is a fact which is offered for direct perception without depending upon a conscious inference from other testimonial or circumstantial facts. Wigmone, CodE of EvIDENCE $\S 200$, at $42, \S 201$, at 44 (3d ed. 1942).

${ }^{10}$ See G. P. Putnam's Sons v. Callisi, 205 A.2d 913, 920 (N.J. Super. Ct. 1964).

${ }^{1}$ See United States v. West Coast News Co., 228 F. Supp. 171, 182-91 (W.D. Mich. 1964); Commonwealth v. Isenstadt, 318 Mass. 543, 557-61, 62 N.E.2d 840, 848-49 (1945). If the Brennan-Goldberg position that "community" is to be given a national signif. cance is adopted by a majority of the Court, this might facilitate the introduction of expert testimony because national community standards would not necessarily be within the peculiar competence of the local jury.

${ }_{62}$ See Yudkin v. State, 229 Md. 223, 228-29, 182 A.2d 798, 801.02 (1962); United States v. West Coast News Co., supra note 41 , at 182-83.

${ }^{48}$ See In re Harris, 56 Cal. 2d 879, 880, 366 P.2d 305, 305-06, 16 Cal. Rptr. 889, 889-

90 (1961); Yudkin v. State, supra note 42, at 227-28, 182 A.2d at 801.02

"See note 38 supra. 
to present evidence as to the "redeeming social importance" of the challenged material, since this is an issue not peculiarly within the jury's competence; it is therefore an issue concerning which expert testimony might be of assistance.45

\section{The Feasibility of the Warren-Clark View}

Given this type of record, it is difficult to imagine how a reviewing court would apply a mere "sufficient evidence" review. If something less than the "substantial evidence" test of Universal Camera means looking only at one side of the record, ${ }^{46}$ then nothing more than the defendant's knowing dissemination of the challenged material could be gleaned from the state's case. If this constitutes insufficient evidence, then the Court would be compelling states to alter their rules of evidence. ${ }^{47}$ If, on the other hand this in itself amounts to "sufficient evidence," it would seem that the test advocated by Warren and Clark is merely a subtle device for obviating protracted consideration of obscenity cases by the Court. ${ }^{48}$ The fact that the state bears the burden of persuasion in criminal prosecutions may well induce presentation of more evidence than is necessary to sustain merely its burden of going forward. Yet so long as an obscenity case can go to the jury on a mere showing that the defendant knowingly disseminated the challenged material, ${ }^{49}$ reviewing courts may be faced with the difficult and perhaps meaningless task of applying a "sufficient evidence" test to a virtually barren record.50

Aside from the prospect that the test may not be susceptible to a meaningful Supreme Court review, the solicitude for a local com-

4S See, e.g., Attorney General v. Book Named "Tropic of Cancer," 345 Mass. 11, 20-21, 184 N.E.2d 328, 334-35 (1962).

'See text accompanying note 31 supra.

${ }^{17}$ See notes 37-40 supra and accompanying text.

${ }^{4}$ That this objective lies at the base of the Warren-Clark advocacy of a "sufficient evidence" review is suggested by their votes against granting certiorari in two subsequent cases. Tralins v. Gerstein, 378 U.S. 576 (1964) (reversing per curiam); Grove Press, Inc. v. Gerstein, 378 U.S. 577 (1964) (reversing per curiam).

${ }^{\circ}$ See cases cited note 36 supra. The challenged material, of course, must be placed in evidence as an exhibit and submitted to the jury for consideration. See text in note 39 supra.

00 If the reason given for allowing the state to go to the jury without presenting evidence on "community standards," "dominant theme," and "appeal" is that these are legal conclusions, it is questionable whether the state could present evidence on these issues even if it chose to do so. If evidence on these issues is precluded, the case against the "sufficient evidence" test is even stronger, since it would be impossible for the record to contain anything more than the defendant's knowing dissemination of the material, the material itself, and evidence as to its redeeming social importance. 
munity standard by Justices Warren and Clark does lend some validity to a "sufficient evidence" test. But even if it be conceded that "community" should be given a local significance, a sufficient evidence test might be obviated by other considerations. Although the Supreme Court would seem incompetent to review a state court determination of the appeal of the material according to local community standards, it would be competent to review a determination of "the dominant theme of the material as a whole." determination does not depend upon "contemporary community standards," for under Roth only the appeal of the dominant theme of the material as a whole is to be judged according to community norms. ${ }^{32}$ Moreover, were the jury to misjudge the dominant theme, it would probably also misconceive both the appeal of the material and its social importance. ${ }^{53}$ The Supreme Court could hold that the dominant theme could not appeal to prurient interest under any community standards. To determine the dominant theme of the challenged material, the Court itself would have to peruse the material since the prevalent rules of evidence tend to preclude any testimony on this issue from appearing in the record..$^{54}$

However, if local standards are emphasized it might be irrelevant that a single theme were found to be "dominant." It could be argued that the members of the local community may be so unsophisticated as to miss the "dominant theme" and detect only a theme that appeals to prurient interest. If a local trier-of-fact would so find, it follows that the community's right to protect its "moral fiber" would suffice to sustain the prohibition of the challenged material. ${ }^{55}$ Were "dominant theme" interpreted as "dominant theme

\footnotetext{
sI Roth adopted "dominant theme" as a part of the constitutionally acceptable definition of obscenity since, "The Hicklin test, judging obscenity by the effect of isolated passages upon the most susceptible persons, might well encompass material legitimately treating with sex, and so it must be rejected as unconstitutionally restrictive of the freedoms of speech and press." 354 U.S. at 489 . The Court expressed the opinion that it is "vital that the standards for judging obscenity safeguard the protection of freedom of speech and press for material which does not treat sex in a manner appealing to prurient interest." Id. at 488.

52 See text accompanying note 1 supra.

${ }^{58}$ For example, if the dominant theme is found to be a portrayal of eroticism in post-war France, the appeal of the material is more likely to be found to be directed to prurient interest, and the material to be lacking in social importance, than if the dominant theme were held to be a protest against war by means of a showing of the moral decay wrought by war. But see Lockhart \& McClure, Censorship of Obscenity: The Developing Constitutional Standards, 45 MINN. L. REv. 5, 72.73 (1960).

st See text accompanying notes 9-11 supra.

${ }_{55}$ This view assumes that the dissemination of obscene material poses a threat to the moral fiber of the community. This was an issue in United States v. Roth, 237
} 
as conceived by the local community," the Supreme Court vis-à-vis a local jury would be as incompetent to discern the "dominant theme" as it would be to ascertain "community" standards. Hence, under this view a sufficient evidence test might still be feasible.

Nevertheless, even if a local significance is accorded "community" and "dominant theme," de novo review by the Supreme Court might still be necessary on the issue of "redeeming social importance." In Roth, the Court upheld the constitutionality of obscenity statutes on the ground that the obscene is "worthless"-"utterly without redeeming social importance"-and therefore not entitled to constitutional protection..$^{56}$ This language may be fairly construed to mean that material must be worthless to satisfy the constitutional standards relating to obscenity; 57 therefore, material whose dominant theme appeals to prurient interest may not be ipso facto proscribable since it may not be "utterly without redeeming social importance." ${ }^{258}$ The highest courts of California, ${ }^{59}$ Illinois, ${ }^{60}$ Massa-

F.2d 796, 798 (2d Cir. 1956). On appeal, the Supreme Court sidestepped the issue by holding that since obscene material is not constitutionally protected, issues relating to the clear and present danger test need not be considered. The lower court, however, was troubled by the fact that "no one can show that, with any reasonable probability obscene publications tend to have any effects on the behavior of normal, average adults ...." Id. at 802 (concurring opinion). For this reason, Justices Warren and Clark cannot base their argument on the unsubstantiated conclusion that the obscene presents a danger to the community, unless they are willing to subscribe to Justice Harlan's argument that state legislatures have discretion to act unless the choice is "irrational." See Roth v. United States, 354 U.S. at 501-02 (concurring in part, dissenting in part).

o0 354 U.S. at 481.85 .

${ }^{67}$ See Kalven, The Metaphysics of the Law of Obscenity, 1960 SUP. CT. REv. 1, 13.

"s On the other hand, it may be argued that "utterly without redeeming social importance" is merely a shortband expression for "material whose dominant theme appeals to prurient interest." Under this approach, all that is obscene is worthless, obscenity is that which appeals to prurient interest, therefore, things whose dominant theme appeals to prurient interest are worthless. This, however, is fallicious reasoning. In logical terminology, this is generally known as the fallacy of illicit distribution and specifically as the fallacy of the illicit minor premise. See, e.g., RuBY, Locic 185-86 (1960). It is equivalent to saying that all lawyers are educated people, all lawyers are talkative people, therefore, all talkative people are educated people.

${ }^{\circ 0}$ California amended its obscenity statute, which was phrased in terms of the Roth test, by adding "and is matter which is utterly without redeeming social importance." Cal. Pen. Code $\$ 311$ (Supp. 1964). (Emphasis added.) In construing this statute, the court in Zeitlin v. Arnebergh, 59 Cal. 2d 901, 383 P.2d 152, 31 Cal. Rptr. 800 (1963) indicated that this amendment made an element of the offense that which was formerly described as a defense. Id. at 918-20, 383 P.2d at 164, 31 Cal. Rptr. at 812 .

${ }^{\circ}$ In People v. Bruce, 202 N.E.2d 497 (IIl. 1964), the court reversed an obscenity conviction despite its feeling that the material was patently offensive and that it transgressed customary limits of candor. The court stated that "no matter how objectionable the method of its presentation,.... [the material] was constitutionally privileged unless it was utterly without redeeming social importance." Id. at 498. 
chusetts, $^{61}$ and New York ${ }^{62}$ have read Roth and subsequent per curiam decisions $\mathrm{s}^{63}$ as indicating this to be the case. Under this view, the application of a sufficient evidence test to judge "community standards" and "dominant theme" would not preclude de novo review of the material by the Court for purposes of evaluating "redeeming social importance." 64

In any event, it is doubtful that a "sufficient evidence" review would in the long run reduce the amount of time which the Court spends in reviewing obscenity cases. ${ }^{\text {bs }}$ Certainly the amount of time spent reviewing any particular case would be reduced. However, a "sufficient evidence" affirmance would have little value with regard to defining the constitutional protection to be afforded the same material. Petitioners from hundreds of other "communities," or even the same "community," might well seek review of the same material under the belief that their evidence is sufficient to overturn their conviction. This would be particularly true if a local community standard is adopted, and the Supreme Court would have to reevaluate the meaning of "contemporary community standards" in every case. On the other hand, a ruling following de novo review, which entails an independent perusal of the challenged material, would tend to discourage petitioners from seeking review of the same material.

A definitive ruling on the material itself, furthermore, might prevent a great many cases from coming to the Court at all, since

"In Attorney General v. Book Named "Tropic of Cancer," 345 Mass. 11, 20-21, 184 N.E.2d 328, 334-35 (1962), the court held that obscenity in the constitutional sense is that which lacks redeeming social significance. By negative implication, it may be argned that material cannot be constitutionally proscribed as obscene and yet possess redeeming social significance.

${ }^{62}$ People v. Richmond County News, Inc., 9 N.Y.2d 578, 589, 175 N.E.2d 681, 687, 216 N.Y.S.2d 367,378 (1961) (concurring opinion). See $i d$. at 586.87, 175 N.E.2d at $685-86,216$ N.Y.S.2d at $375-76$.

${ }^{a}$ Sunshine Book Co. v. Summerfield, 355 U.S. 372 (1957); One, Inc. v. Olesen, 355 U.S. 371 (1957); Times Film Corp. v. City of Chicago, 355 U.S. 35 (1957).

of One could argue that under the Warren-Clark philosophy "redeeming social importance" should logically be given a local significance, "social" referring to the local community.

${ }^{\circ}$ This would be particularly true if "sufficient evidence requires reading or viewing the entire material. See note 32 supra.

It appears that the Warren-Clark dissent was motivated primarily by distaste for the prospect of the Supreme Court acting as the ultimate censor for the United States in all obscenity cases. It is probably this concern which has compelled them to adopt the local community and sufficient evidence standards, which are admittedly intended to vest primary responsibility for administering the law of obscenity in the bands of local tribunals. See 378 U.S. at 199-200, 202-03. 
state appellate courts might, by analogy to materials already held to be constitutionally protected by the Supreme Court, reverse the conviction. Moreover, utilization of this analogy reasoning might force local prosecutors to be more selective in the indicting process. Since the concept of obscenity is not conducive to definitive legal standards, it can be argued that the Supreme Court can best guide other tribunals by creating a series of precedents upon which state and lower federal courts may reason from analogy. ${ }^{66}$

\section{ConcLusion}

On balance, the Warren-Clark alternative to de novo review in obscenity cases does not seem feasible. The rules of evidence which have evolved in this area would appear to render a "sufficient evidence" test meaningless. Even assuming its workability, such a test would seem an ineffective and short-sighted attempt to better administer the Court's business. It is also questionable whether the theoretical basis of the Warren-Glark approach, which accords a local significance to "community," would preempt the Court from undertaking a de novo review of the evidentiary basis of a "constitutional judgment" in light of the remaining issues of "dominant theme" and "redeeming social importance."67 Hence, unless the Court is willing to take the unlikely step of adopting the BlackDouglas view that all obscenity laws abridge freedom of expression and are therefore unconstitutional, it would appear that de novo review is in order. ${ }^{68}$

${ }^{00}$ See Larkin v. G. P. Putnam's Sons, 14 N.Y.2d 304, 252 N.Y.S.2d 71, 200 N.E.2d 760 (1964). There the court noted that the United States Supreme Court had overruled convictions involving Tropic of Cancer and Pleasure Was My Business; since it did not consider Fanny Fill to be any worse than the books already accorded constitutional protection, it refused to affirm an order restraining the sale and distribution of Fanny Hill. Contra, G. P. Putnam's Sons v. Callisi, 86 N.J. Super. 82, 205 A.2d 913 (1964) (rejecting the analogy test).

${ }^{\circ 7}$ It should be noted that since the decision in Roth, the Supreme Court has failed to uphold a single obscenity conviction. See Tralins v. Gerstein, 378 U.S. 576 (1964) (per curiam); Grove Press, Inc. v. Gerstein, 378 U.S. 577 (1964) (per curiam); Manual Enterprises, Inc. v. Day, 370 U.S. 478 (1962); Smith v. California, 361 U.S. 147 (1959) (statute unconstitutional for complete lack of scienter); Sunshine Book Co. v. Summerfield, 355 U.S. 372 (1958) (per curiam); One, Inc. v. Olesen, 355 U.S. 371 (1958) (per curiam); Times Film Corp. v. City of Chicago, 355 L.S. 35 (1957) (per curiam). While opinions have been rendered in some cases, in none was there an opinion of the court.

${ }^{\circ B}$ Despite the diversity of opinion in Jacobellis, and in light of the subsequent per curiams, see note 67 supra, there seems to be a solid five-four majority in support of the judgment embraced in the Brennan-Goldberg opinion. Presumably Justices Black and Douglas will vote consistently to grant certiorari and for reversal, due to their more extreme position. Mr. Justice Stewart, in his belief that obscenity prosecution should 
be limited to hard-core pornography, intends to see the material in order to judge whether it is hard-core pornography. He would therefore vote to grant ccrtiorari and perform something more than a sufficient evidence test. In Tralins v. Gerstein and Grove Press, Inc. v. Gerstein, supra note 67, he voted to reverse. Hence, even with the loss of Mr. Justice White to the dissenters in those two cases, there appears to be a majority of five Justices which will continue to reverse in the post-Roth manner.

See Kalven, The New York Times Case: A Note on "The Central Meaning of the First Amendment," 1964 SuP. CT. REv. 191, 217-18, wherein it is argued that since New York Times Co., v. Sullivan, 376 U.S. 254 (1964), "no matter how speech is classified, there must still be First Amendment consideration and review. No category of speech is any longer beneath the protection of the First Amendment. . . [Obscenity] 'can claim no talismatic immunity from constitutional limitations." " 